\title{
Retired Yet Involved: How Even After the Succession Predecessors of Family Businesses Continue to Influence Their Firms
}

\author{
Sinan Caykoylu ${ }^{1}$ \\ ${ }^{1}$ School of Management, New York Institute of Technology, Vancouver, Canada \\ Correspondence: Sinan Caykoylu, MBA Program, 1700-701 W. Georgia St., Vancouver, BC, Canada. E-mail: \\ scaykoyl@nyit.edu
}

Received: October 1, 2018

Accepted: December 20, 2018

Online Published: January 25, 2019

doi:10.5539/ijbm.v14n2p19

URL: https://doi.org/10.5539/ijbm.v14n2p19

\begin{abstract}
Successions are usually portrayed as events where predecessors quickly and quietly fade away from the picture once the transfer of managerial authority is complete. However, for majority of the family firms this is not the case. Family firm predecessors can continue to be involved with the family business even after their retirement in myriad of ways through on-going and overlapping business and kinship relations. Based on interviews with predecessors and successors from nineteen family businesses in Turkey, this article presents that it is the successors' expectation how their predecessors should act after the succession that determines whether post-succession predecessor involvement has a positive or negative influence on the family business.
\end{abstract}

Keywords: Succession in family businesses, continued predecessor involvement, predecessor-successor interactions

\section{Introduction}

Succession in family businesses is seldom a seamless and continuous transition that ends with the "transfer of the baton" (Sigalas et al., 2008). Academic research and anecdotal evidence suggest that even after the transfer of managerial title and responsibilities, if the predecessor is still alive and able-bodied (physically and mentally), we should not automatically assume post-succession predecessor involvement will diminish or disappear. Predecessors can decide to continue to be involved with the family business in different capacities for different reasons (Cabrera-Suarez, 2005; Cadieux, 2007; Chung and Yuen, 2003; Feltham, Feltham and Barnett, 2005). For example, Stavrou (2003) found that most parent-predecessors, who had technically retired, desired to stay involved in their firms and continue to advise their heirs on how to manage, in a genuine attempt to be helpful to the firm and the offspring. Using anthropological theory, Grote (2003) argues that predecessors might not want to sever their ties with the family business after the succession because it reminds them of their own mortality and because the firm has become a surrogate family that they do not want to abandon.

It is the interlocked spheres of family, management and ownership in family businesses that makes it possible and easier for predecessors to find alternative ways to continue to be involved with the family business (Harvey and Evans, 1995). Often incumbents and successors have a parent-child or senior family member-junior family member relationship (Jayaraman et al., 2000). In addition, during predecessors' tenure they can build influential and loyal network ties with other stakeholders (i.e. other family members, employees, suppliers, customers, etc.). After their retirement, predecessors can still continue to be involved with the family business via commanding family relationships or loyalties of their networks (Davis \& Harveston, 1998). Basically, predecessors who have given up their top managerial titles could still hold on to certain authority and power through their stocks, legacy, and family authority

If retired predecessors can and often do continue to be involved with the family business even after the succession, it becomes important to understand how post-succession predecessor actions could influence successors and the family business. To this end, this research has two objectives: a) explore the different post-succession behaviours predecessors display by identifying the discriminating components of their actions, and b) examine the consequences of varying continued predecessor involvements on successor attitudes and the well-being of the family business. 


\section{Literature Review}

\subsection{Reasons behind Continued Post-Succession Predecessor Involvement}

Continued predecessor involvement could be based on reasons like wanting to ensure family harmony, helping the new successor and assuring continuity in certain aspects of the business, but there could also be personal reasons such as not fully trusting the successor, lack of alternative activities, and reaffirming self-worth (Cater \& Justis, 2010; Kets de Vries, 2003; Quigley \& Hambrick, 2012; Sharma et al., 2001). Some predecessor might resist decreasing their involvement with the organization to ignore the signals of their mortality (Davis and Harveston, 1998; Handler, 1990). Most predecessors, at great personal cost, invest a large part of their time and resources into the company (Cater \& Justis, 2010) and when individuals are separated from projects they are heavily invested in, this decreases their morale so much that they are willing to return to the project under less desirable circumstances (Mochon, Norton \& Ariely, 2012).

Continued predecessor involvement can be attributed to the predecessors' desire to ensure they are leaving their heirs a healthy and sound organization that could potentially exist for decades (Bjuggren \& Sund, 2001; Le Breton-Miller \& Miller, 2006; Miller \& Le Breton-Miller, 2005). This urge could be especially pressing when the intended successors are the children of incumbent CEOs (Grassby, 2001; Lansberg, 1999). When predecessors feel that their chosen successor might be challenged by the other potential candidates, they could continue involvement in order to provide support for the successor and protect family harmony (Lansberg, 1999). Finally, most predecessors know their retirement income will depend on the well-being of the business; hence, they might be reluctant to give up the opportunity to observe and/or control how the family business is managed if they perceive doing so would jeopardize their retirement income and legacy (Sharma, Chua \& Chrisman, 2000).

\subsection{The Influence of Post-Succession Predecessor Involvement}

Davis and Harveston (1998) and Mitchell, et al. (2009) simply categorizes post-succession predecessor behaviours as "being involved" or "not being involved;" arguing that the former always leads to negative outcomes. Studies by Sonnenfeld (1988) and Cadieux (2007) argue that predecessors do not assume a singular post-succession involvement role and that their involvement could evolve overtime. They argue that predecessor personalities and retirement circumstances influence the post-succession level of involvement on a continuum ranging from "high" to "low". Cabrera-Suarez (2005) through her case study argues that high levels of involvement will lead to negative outcomes but the low-level involvements can actually be beneficial for the organization if managed well.

In family businesses, if predecessors' post-succession behaviours create inertia for change and they try to keep time still, this can lead to friction and conflict among successors who perceive a need for change (Miller, Steier \& LeBreton-Miller, 2003). Studies examining the impact of post-succession predecessor involvements in family businesses (e.g. Mitchell et al., 2009) confirm that increased predecessor involvement challenges successors' control over the organization by hindering their ability to develop and implement appropriate strategies. Harvey and Evans (1995) argue that since predecessors do not usually act as change agents, their continued involvement will mostly lead to friction between them and their successors, causing successors to negatively react towards the predecessor and the family business. However, social norms governing parent-child relationships can influence successors' reactions to their predecessors' post-succession actions. If successors are aware of their parent-predecessor's sincerity to help them, they can display less of an objection for their parent-predecessors' post-succession actions in order to avoid hurting their parents' feelings and/or to prevent damaging family relations (Rosenblatt, de Mik, Anderson \& Johnson, 1985). In her 2005 case study, Cabera-Suarez provides examples showing how predecessors who have encouraged and supported their successors by allowing them to take responsibility and make mistakes generated positive successor reactions. The author describes in her study a context in which predecessors do not conflict with successors but cooperate with them by sharing the workload and providing advice.

In addition, studies show that negative successor attitudes towards the predecessor, organization and/or the succession process could lead to increased intergenerational conflicts and deterioration of the family harmony (Brun de Pontet, Wrosch and Gagne, 2007; Venter, Boshoff and Maas, 2005). The dyadic interaction between predecessors and successors is important because if managed properly it builds greater trust, better understanding and opportunities for improved knowledge transfer among the actors (Cabrera-Suárez et al., 2001; De Massis, Chua \& Chrisman, 2008; Handler, 1990,Harvey \& Evans, 1995; Sharma et al., 2001, Ward, 1987), and it is linked directly to improved successor post-succession performance (Goldberg, 1996) and positive organizational outcomes (Handler, 1990; Le Breton-Miller et al., 2004; Stavrou \& Swiercz, 1998; Venter et al., 2005). However, if the dyadic interaction between the predecessor and successor starts to deteriorate this could lead both to erect barriers hindering effective communication, adopt destructive roles and avoid each other's company; preventing 
critical resource sharing (Gordon \& Nicholson, 2010) all of which can heart the well-being of the organization (Danes, Leichtentritt, Metz, \& Huddleston-Casas, 2000; Stewart \& Danes, 2001).

\section{Research Methodology}

The methodology required for this research had to provide the opportunity to identify particular attributes and their dimensions, compare these across cases and identify a pattern from the systematic comparison among cases. To achieve this goal and to identify such patterns, qualitative research methods, especially a grounded theory approach was particularly well-suited for this research (Gilgun \& Sussman, 1996). Guided by the requirements of grounded theory methodology, the first step was to decide which organizations to approach for data collection.

The ongoing debate as to what kind of organization could be considered a family business and the focus being on the post-succession period meant that participants had to be selected from family businesses that fulfilled certain conditions. First, to ensure only organizations that fit the theoretical family business definition provided by Chua, Chrisman and Sharma (1999) were considered, the following factors about the organizations were controlled for: the amount of stock owned by a member or members of a single family had to represent the majority of the company shares, at least one family member had to be involved in the management activities, and there had to be the intention to keep the business sustainable, at least for the next generation family member(s). Second, in order for participants to be able to provide first-hand information about the post-succession period, they had to have gone through a succession in their family business. Potential participants were specifically asked to confirm succession in their family business had happened. This was important because the belief of passing over a threshold (i.e. the transition) influences peoples' future expectations and behaviours compared to changes in their official titles (Handler, 1989). Finally, there needed to be confirmation that the succession was not brought about by the predecessors' sudden death or a debilitating mental or physical illness. The purpose for this criterion was to ensure that the predecessors had the opportunity to choose between continued post-succession involvement or not.

The next step was to decide whom to pursue in family businesses to participate in this research. Both predecessors and successors were identified as suitable participant candidates that could provide first-hand data for this research. Members from both genders were included in the research; however, the total number of women participants was low (only 2 out of 24 in the final sample), reflecting the comparatively low numbers of female family members who are involved in the management of family businesses (Cadieux, Lorrain, \& Hugron, 2002). To determine if different levels of familial connections mattered in post-succession involvement, there was no restriction based on whether potential research participants were in a parent-child relationship. However, all of the predecessor-successor relationships ended up also being parent-child relationships.

For this research data were collected from family businesses in Turkey. Unfettered access to the local Independent Industrialists and Businessman's Association (MUSIAD (Note 1)) membership list made it possible to gain access to significant number of potential participants in a reasonable amount of time. Support of the association also helped ensure the trust relationship regarding how the sensitive information will be used during and after the research. Participants came from 19 family businesses (FB). Eighteen of the family businesses were $100 \%$ family owned and operated and could be classified as mid-size firms based on their revenues and number of regular employees. Only one FB was a publicly traded company where the family still controlled the majority of the shares and family members were involved actively with the management of the company by occupying the positions of chairperson, CEO, sales and marketing director. Predecessors were mostly majority shareowners while successors were minority shareowners.

To protect the anonymity of the participants, both family businesses' names and respondents' names were replaced with an alphanumeric code (i.e. "FB-number" for the family business). Depending on whether the participant was a successor or a predecessor, the letter "S" or "P" was placed after the alphanumeric code. In total, from the nineteen family businesses, 24 individuals agreed to participate in this research; fifteen were successors and nine were predecessors. Most of the participating successors were middle-aged males with a university or higher degree education. The predecessors, on the other hand, were usually over the legal retirement age, were all males, and most had only equal to or less than a high school diploma. All of the family businesses were officially managed by the second generation; the predecessors were the founders of these firms. A summary of the characteristics of the family businesses and interviewees participating in this research is provided in Table 1 below. 
Table 1. Characteristics of the family businesses and the participants

\begin{tabular}{|c|c|c|}
\hline A. A. Family Businesses & \multicolumn{2}{|l|}{$N=19$} \\
\hline \multicolumn{3}{|l|}{ Industry } \\
\hline Manufacturing & \multicolumn{2}{|l|}{5 (FB's $1,2,5,14,17$ ) } \\
\hline Construction & \multicolumn{2}{|l|}{4 (FB's 8,9,10,16) } \\
\hline Textile & \multicolumn{2}{|l|}{3 (FB’s 6,11,12) } \\
\hline Food and Beverage & \multicolumn{2}{|l|}{2 (FB's 13, 15) } \\
\hline Legal Service & \multicolumn{2}{|l|}{1 (FB 19) } \\
\hline Automotive & \multicolumn{2}{|l|}{1 (FB 18) } \\
\hline Optic Supplies & \multicolumn{2}{|l|}{1 (FB 7) } \\
\hline Tourism & \multicolumn{2}{|l|}{1 (FB 3) } \\
\hline Freight & \multicolumn{2}{|l|}{1 (FB 4) } \\
\hline \multicolumn{3}{|l|}{ Number of Employees } \\
\hline 49 or less & \multicolumn{2}{|l|}{9 (FB's $2,6,8,9,10,11,15,19)$} \\
\hline $50-99$ & \multicolumn{2}{|l|}{$4(\mathrm{FB}$ 's $7,16,17,18)$} \\
\hline $100-250$ & \multicolumn{2}{|l|}{4 (FB's $1,3,12,14$ ) } \\
\hline 251 or more & \multicolumn{2}{|l|}{2 (FB's 5,13$)$} \\
\hline \multicolumn{3}{|l|}{ Transfer of ownership } \\
\hline Predecessor Owned & 11 (FB's $2,3,6,8,12,13,14,15$ & \\
\hline Successor Owned & 5 (FB’s $1,4,5,7,9,10,19)$ & \\
\hline Other & $1 *($ FB 11) & \\
\hline B. B. Interviewees & & \\
\hline & Successors $(\mathbf{N}=15)$ & Predecessors (N=9) \\
\hline Average age (S.D.) & $44.5(5.0)$ & $70.7(4.5)$ \\
\hline Gender & & \\
\hline Female & 2 (FB's 12,13$)$ & -- \\
\hline Male & 13 (rest of the successors) & 9 (all the predecessors) \\
\hline Education level & & \\
\hline Graduate degree & 5 (FB’s $1,8,12,13,16$ ) & 1 (FB 19) \\
\hline Undergraduate degree & 10 (rest of the successors) & 3 (FB's $2,4,18)$ \\
\hline High School diploma & -- & 4 (FB's $1,3,5,16$, ) \\
\hline Less than 12 years & -- & $1(\mathrm{FB} 17)$ \\
\hline \#Generation & & \\
\hline First (Founder) & - - & 9 (all the predecessors) \\
\hline Second & 15 (all the successors) & -- \\
\hline
\end{tabular}

*Successor shares equal ownership with his partner/uncle (50-50 split).

Semi-structured in-depth interviews were the primary source of data for this research. The interviews began by asking participants to provide information in their own words about the family firm (i.e. when/how/by whom was it established, its history up until now and future expectations), their personal and career history and family involvement with business. These questions were then followed with inquiries about events/actions/interactions that transpired after the succession in the organization, in the family and between the predecessor and the successor. Participants were encouraged to explain from their own perspective their reactions and feelings. Before concluding the interviews, demographic and personal information was collected from the participants. During the interviews, participants were encouraged to take the lead and express their thoughts freely without interruption. The length of the interviews varied between 45 minutes to two hours, and process notes were taken immediately following each interview. However, it is important to note that the interviews were not designed in such a way that a set of structured questions were asked in the same order all the time. Depending on the pace and information provided by the participants, the wording and order of the questions were modified during the interviews. The interview questions and the inquiry style took their final shape out in the field while actually interacting with the participants and collecting data.

To triangulate the data, further information about the family businesses and the participants were collected from two different sources: company generated materials (e.g. annual reports, company brochures and websites) and third-party generated materials (print and web-based media). The secondary sources were used primarily to gather 
additional information about the family business, the family and the participants. In some cases, the secondary data confirmed some of the information that was provided by the participants during the interviews. Events that took place in the public eye also provided a starting point to discuss matters that were personal in nature.

Data analysis for this research began as soon as first data were collected (Marshall \& Rossman, 2006). After each interview the voice recordings and field notes were transcribed as soon as possible. Process notes including themes, interpretations, ideas and interesting quotes were noted as memos and attached to the participant's file. Once an interview record was transcribed, transcriptions were read line by line, and a new code was created whenever a statement was discovered that indicated an incident not yet covered by any of the previously introduced codes. No preconceived codes were used during the data analysis process. All of the codes freely emerged during the analysis of the data. Coding properties of incidents such as context, interaction among parties and consequences also were noted freely (Strauss \& Corbin, 1990). Evidence from new cases was continually compared while remaining open and sensitive to the emergence of new incidents not previously covered.

After finishing the initial first-level coding, each code was re-examined to ensure that they accurately represented the incidents to which they were assigned and to determine whether some codes should be split, combined or renamed (Gioia, Corley, \& Hamilton, 2013). Moving to the second order categorization, or in other words, grouping first-level codes into code families, reduced the germane categories into a more manageable number (Gioia et al., 2013). Code families were further linked to higher order concepts called "themes." Since this research collected data from two different groups of participants (predecessors and successors) and was interested in both successor and organizational outcomes, the themes were further categorized according whether they were related to predecessor actions, successor reactions or organizational outcomes. This further categorization of data was done to develop a more parsimonious conceptual framework for explaining the outcomes of post-succession predecessor involvement. This higher-level conceptualization was necessary to make the emerging framework more solid by using parsimonious concepts with higher explanatory power. In addition, it is considered a key component of demonstrating rigor in qualitative research (Pratt, 2008).

To minimize bias and further improve the reliability of the process, the help of an independent business faculty member who is familiar with qualitative studies was obtained. Free rein was given to the independent coder to go beyond the coding guideline, and to identify new ways of coding and new words for the codes. Comparison between the two sets of coding revealed $83 \%$ agreement. The minor differences were mostly due to redundancies and the choice of words used to name codes. After careful deliberation, all of these issues were resolved quickly.

\section{Results}

All of the participants reported that in one form or the other there was continued predecessor involvement at their family business post-succession. This reaffirms previous researchers (e.g. Cadieux, 2007; Davis \& Haveston, 1998; Harvey \& Evans, 1995; Sonnenfeld, 1988) and practitioners arguments, even after predecessors and/or successors claim that the succession in the family business has occurred, this does not mean that the previous generation has stopped their involvement with the organization. From the beginning of the research it quickly and consistently appeared that participants differentiated predecessors' post-succession involvement behaviour based on how often it occurred, how intense it was and how wide an influence it had.

\subsection{The Involvement Dimensions}

Frequency of the predecessors' post-succession involvements differed as if they were on a continuum where at the one end there was constant contact with the organization and its stakeholders, and on the other end there was barely any noticeable contact with the organization and its stakeholders (see Figure 1). Predecessors, who monitored events in and around the organization on a regular basis, who made their presence felt at the office, regularly examined official reports, kept in touch with different stakeholders on an ongoing basis and/or often took part in the strategic decision-making processes, were considered to be frequently involved with the family business. On the other hand, predecessors who did not come to the office regularly, seldom checked reports and tried to avoid taking part in decision-making processes were considered to be infrequently involved with the organization. It emerged that in eleven of the family businesses the predecessor's involvement level was high and in eight of them it was low.

The second matter participants focused on when talking about post-succession predecessor involvement was the style predecessors employed (see Figure 1). Participants described predecessor behaviours either as an active attempt to try to force the successor's decisions and behaviour to be in alignment with their own or as providing alternative views and solutions to the successor's without imposing their will or desires onto successors. These descriptions are similar to the "directive" versus "consultative" style leaderships (Bass, 1990; Pelletier, 2010). Hence, an involvement can be deemed directive in style when predecessor involvement leads to strategic 
organizational decisions to be made in alignment with the desires and/or needs of the predecessor rather than the desires of the successor and/or the needs of the organization. On the other, consultative style involvements are when predecessors just share their views, thoughts or knowledge and do not impose their will onto the next generation. Participants reported that in twelve of the family businesses the predecessor's involvement style was directive while in seven of them it was consultative.

After the succession, predecessors can choose to be involved with the whole of the organization or decide to limit their involvement to a certain area or issue of the business (see Figure 1). Being involved with the whole of the organization involves monitoring the whole of the organization and dictating decisions or giving advice about matters that would impact the entire organization and its stakeholders. On the other hand, when predecessors feel the need or want to help their successors in certain areas where they think their expertise could be beneficial, or when the successors perceive a desire for this within their predecessors, this type of involvement becomes limited in scope. It emerged that in eleven of the family businesses the predecessor's involvement scope was limited while in eight of them it encompassed whole of the organization.

\section{Frequency:}

High: "Dad was always here watching over my shoulder. On top, he always wanted to take part in every managerial decision I made." (FB-14.S)

Low: "After we took over dad dropped by once in a while to check how we were doing or to deal with old customers who insisted on negotiating with him." (FB-9.S)

Style:

Directive: "He might listen to you but once he makes ups his mind there is no going back. He will find a way to make sure you follow suggestion, if you could call it a suggestion." (FB-6.S)

Consultative: "My role is to be a figurehead and provide advice based on my knowledge and experience. Whether they take it or not is their choice." (FB-19.P)

Scope:

Wide: "Nobody looks after the property of the owner like the owner himself; thus, I always have to be alert and follow everything on the factory floor." (FB-2.P)

Limited: "His [the predecessor's] only responsibility is to look after the accounting department." $(F B-15 . S)$

Figure 1. Examples of the dimensions

\subsection{Post-Succession Predecessor Behaviours}

When these three dimensions are combined (see Figure 2) two distinct post-succession predecessor involvement patterns emerge. It seems that although predecessors can choose any combination of post-succession behaviour along these dimensions they tend to prefer two types of involvement behaviour. In the first type, the predecessor frequently tries to dictates his/her vision about how the whole company should be managed post-succession. In the second type of continued post-succession involvement, the predecessor seldom provides alternative suggestions, like a consultant, limited to only specific matters about the organization. It appears there is a strong relationship between these dimensions; high frequency, directive style and whole organizational scope post-succession predecessor involvements are regularly exhibited together. In a similar fashion, low frequency, consultative style and limited scope post-succession predecessor involvements are regularly exhibited together. 


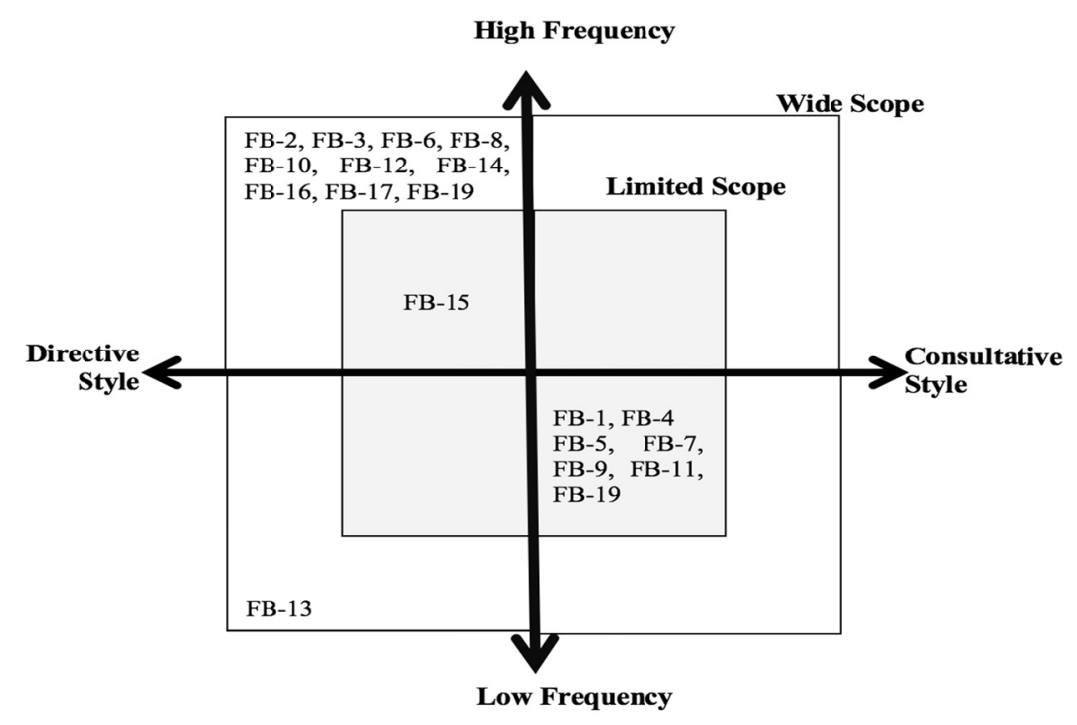

Figure 2. Post-succession predecessor involvement behaviours in the family businesses

Predecessors report that trust towards the successor, comfort with uncertainty and involvement with alternative activities influence their post-succession involvement behaviour choices (see Figure 3). The more predecessors trust their successors, are comfortable dealing with uncertainty and/or are involved in allernative activities, the more they prefer to adopt an involvement behaviour where they provide advice only on issues that they are consulted on. On the other hand, when predecessors do not have high levels of trust towards their successors, are not comfortable dealing with uncertainty and/or have limited involvement with alternative activities, they tend to get involved with the family business in way where they display oversight over the whole organization and regularly dictate his/her wishes to the other stakeholders. Research examining incumbents desire to cede control to their successors (i.e. Cabrera-Suárez et al., 2001; De Massis et al, 2008; Handler, 1990; Ling, Baldridge \& Craig, 2012) corroborates the findings regarding the influence trust towards the successor, comfort with uncertainty and involvement with alternative activities have on predecessors' post-succession involvement choices.

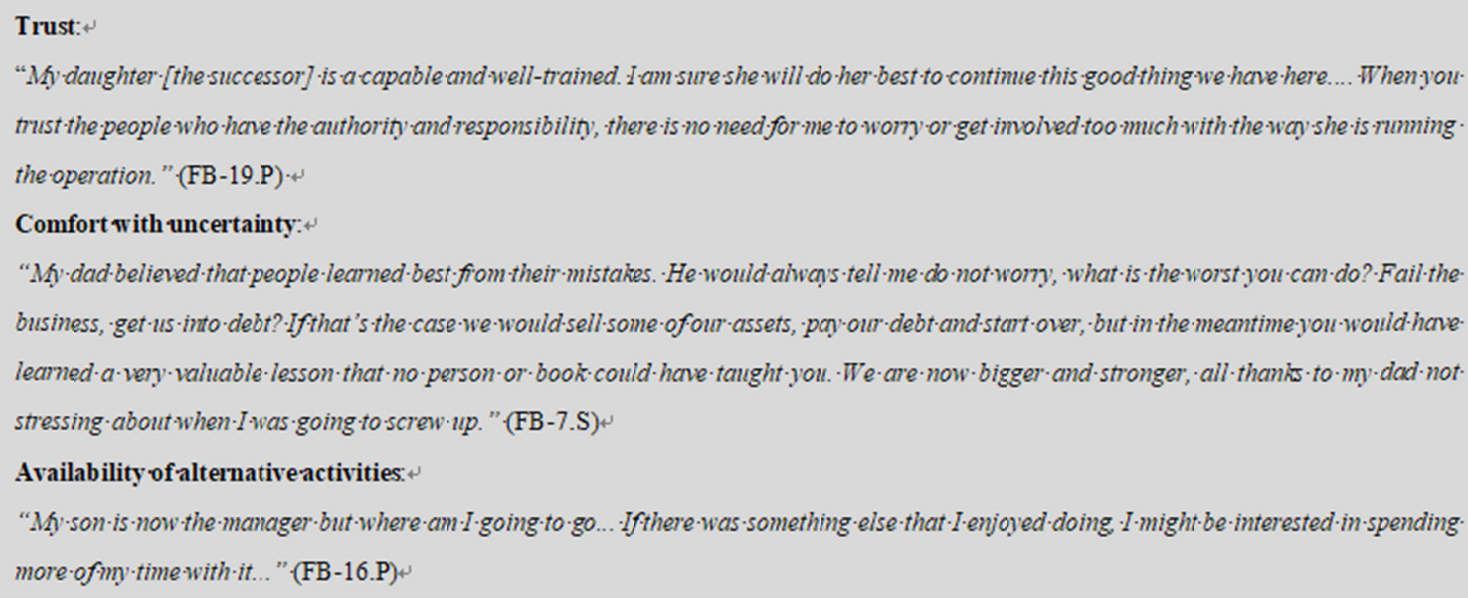

Figure 3. Examples of factors influencing predecessors' involvement decisions

\subsection{Successor Reactions}

From successor responses it was clear that post-succession predecessor behaviours led successors to react, and the nature of the reactions were influenced by whether the successors were expecting or demanding the particular post-succession predecessor behaviour or not. Considering that predecessors' post-succession actions are, for the 
most part, perceived as complementing or conflicting with their successors' management decisions, it is not surprising to expect and observe successors to be the first to react. Successors' reactions regarding their predecessors' post-succession involvement are especially important when we consider that successor satisfaction is strongly linked to the well-being of the firm under their tenure (Sharma et al., 2001).

A number of studies show that unanticipated behaviours (i.e. the discrepancy between what is encountered and what was expected) can lead to various negative outcomes, such as emotional exhaustion (Proost, Ruysseveldt and Dijke, 2012), lower organizational commitment (Wanous, Poland, Premack \& Davis, 1992), and increased turnover intentions (Houkes, Janssen, de Jonge, \& Bakker, 2003; Turnley \& Feldman, 2000). In family businesses, when family members, especially the successors, are not engaged properly (i.e. behaving contrary to their expectations) this damages their sense of fairness within both the organization and the family, and it can ultimately hurt the organization's survivability (Van der Heyden, Blondel, \& Carlock, 2005).

From this research it emerged that successor reactions were either functional or dysfunctional in nature depending on the overlap between actual predecessor involvement behaviours and successors' post-succession expectations from them. Functional reactions are when successors are willing to work together with their predecessors, despite their involvement, to generate ideas, pathways and solutions to tackle problems and enhance the achievement of individual and organizational goals. Functional reactions can ensure that both predecessors and successors work together to find a satisfactory solution before stress and conflicts spiral out of control (Reddy, 1994). On the other hand, a dysfunctional reaction is when the successor disagrees with the predecessors' actions, has an increase in negative feelings towards the predecessor, limits interaction with the predecessor and spends time and resources to undo or undermine the predecessor's action rather than collaborate with each other to achieve individual and organizational goals.

In this research, the successors wanted to benefit from their predecessors' experiences and network connections but did not want their management to be openly challenged or hindered by the post-succession involvement. In majority of the family businesses (fifteen) the desired predecessor involvement behaviour was low frequency, consultative style and limited scope. On the other hand, among the four family businesses (FB-10, FB-11, FB-12 and FB-15) that wanted their predecessors' to be involved in high frequency and directive style involvement, three of them (FB-10 , FB-11 and FB-12) did not consider limiting the scope while one (FB-15) wanted it to be limited to the area of accounting. In the cases where a higher frequency, directive style predecessor involvement was expected, the successors needed their predecessors to either act as a counterweight against other important family members (FB-11 and FB-12), continue to learn by being at their presence (FB-10) or benefit from their specialized knowledge (FB-15) (see Figure 4). In eight of the family businesses it was reported that predecessor's post-succession involvement overlapped with what the successors expected, while in eleven of the family businesses there was a gap (see Figure 5).

To act as a counterweight against other family members:

"I [the successor] am working with my brother, the head of finance, and his wife, the head of public relations. To ensure that my decisions are not second-guessed or I am out voted; having dad's stamp of approval becomes very invaluable. That is why despite his desire to retire completely I make sure he comes to work every day, shares an office with me and follows up on the business." (FB-12.S)

To learn more from the predecessor:

"Dad [the predecessor] wanted to leave everything to us, but we asked him to continue to be involved as actively as he could because we had a great deal more to learn from him. He knew all the important buyers and sellers in this industry; he had this ability to judge people and determine if they were good or bad to do business with. You cannot buy this kind of ability, but when dad was around, he provided it for free. Not wanting to benefit from his wisdom and knowledge would have been stupid." (FB-10.S)

To benefit from their specialization:

"My Dad [the predecessor] by profession is a charted accounted. When I took over the general management I asked him to head the accounting department. This saved the company money but not having to hire a professional." (FB-15.S)

Figure 4. Examples of successors desiring high frequency and directive style post-succession predecessor involvements 
It emerged that when predecessors acted the way their successors wanted them to, irrespective of the involvement behaviour type, the successors felt positively about the situation and they believed that it made it easier for them to run the family business either by consulting or transferring some tasks to the predecessor or by not having to deal with problems caused by conflicting management decisions. However, in many cases (eleven) the predecessor involvements were not in line with the successors desires, which made the successors uncomfortable. The successors were unhappy with this situation because they felt they were not being trusted and had to deal with the additional challenges put forth by their predecessors. For example, in the case (FB-11) where the successor needed his predecessor-father to actively help him deal with his partner-uncle ( $50 \%$ owner of the company); the father refused to do so and the successor lost his strength to deal with his uncle, lost commitment towards the family business, stopped caring about the business and allowed it to go bankrupt so he could take on other endeavours, all the while blaming his father.

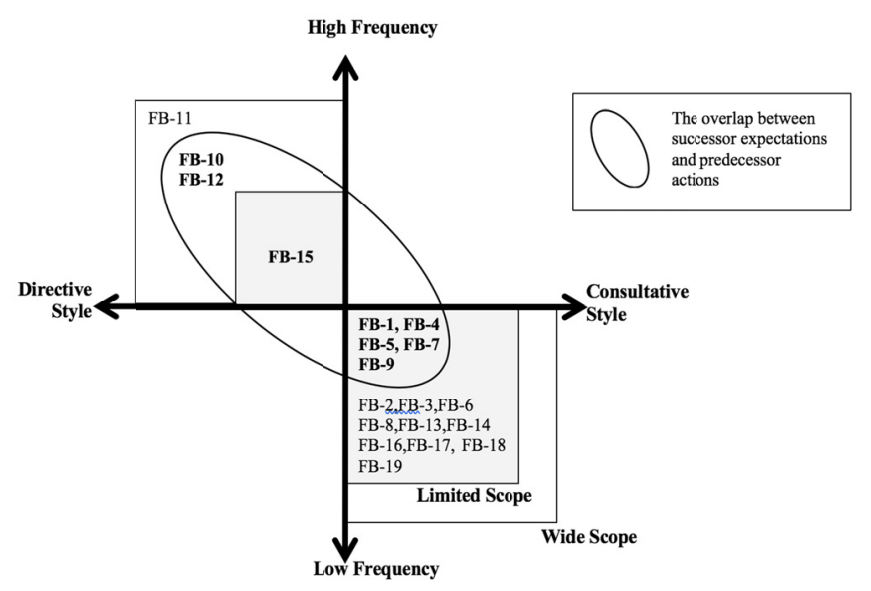

Figure 5. Post-succession successor expectations and overlap with actual predecessor actions

\subsection{Post-Succession Involvement and Organizational Outcomes}

The participants believed that "family" and "business" spheres of influence were interlocked with each other and the nature of their action, reactions and interactions influenced the well-being of the organization. One predecessor (FB-19.P) indicated that the strength of the bond between these two spheres of influences will not guarantee the success of the business, but the weakness of it will definitely mean trouble for the organization and eventually the family business. Both predecessors and successors participating in this research believed and indicated a positive relationship between functional interaction and organizational well-being in the form of perceived expectation of growth and longevity. Functional successor reactions led to more cooperation and sharing of resources, and a decrease in conflict; eventually paving the way for a work environment that was conducive to developing and implementing necessary strategic decisions in an effective and efficient manner. On the other hand, dysfunctional reactions led to a work environment that hindered the development and implementation of necessary strategic decisions by moving in the opposite direction.

Predecessors believed that a functional successor reaction contributed to the well-being of the organization because it allowed them to order or suggest what they thought were necessary investment decisions and strategies to handle critical stakeholders. For example, one predecessor (FB-19.P) indicated that old clients wanted to continue doing business with him and not with the successor because the old clients knew his (the predecessor's) capabilities and style. The predecessor indicated that his successor's functional reaction allowed them to devise a strategy that kept him involved with the family business in order to help old clients get used to working with the new management team. On the successors side, they believed that functional reactions created a work environment where they had better access to idiosyncratic resources, allowed them to multitask and freed them from mundane tasks; thereby giving them the opportunity to focus on developing and implementing new strategies. Successors also indicated that functional interactions that increased their commitment to the organization and made them want to work even harder.

When the successor reactions were dysfunctional this hurt the well-being of the organization because it prevented the management team from making the necessary strategic investment decisions and created the appearance that there was no unity or harmony among top management of the family business. The successors believed that if the family business was going to survive and grow for the future, investments in certain areas such as marketing, 
infrastructure development and product diversification, which had been neglected by their predecessors, had to be done as quickly as possible. However, these successors also felt that their predecessors' continued involvement prevented them from making and implementing strategic investment decisions, causing them to react negatively, creating a hostile work environment and leading them to conclude that the well-being of the family was not served. In addition, appearance of disunity hurt the organization in several ways. The participants reported that when a new procedure or rule was not liked by the old suppliers, customers or employees, these stakeholders tried to use the disunity among top management to continue to do business as if nothing had changed. One successor (FB-14.S) reported that he wanted to introduce a new automated ordering system for the suppliers and the customers, thus eliminating purchase and sales deals without any paper trail, which the old system was notorious for. However, the system never took off until he removed his father (the predecessor) from the business, because both the old suppliers and customers were not willing to be part of the system and continued to deal the old way with the father.

If we summaries the findings of this research, it appears events and interactions that take place between predecessors and successors after the succession are as interactive and influential as the events and interactions prior to the succession. It seems that after the succession, predecessors either prefer to be regularly involved with the family business, dictating and ordering their successors what to do (i.e. frequent-directive-wide scope), or they choose only to give advice when it is needed and requested in regard to specific issues (i.e. infrequent-consultative-limited scope). Personal factors that influence predecessors' desire to initiate and transfer control to the successor during the pre-succession period similarly influence their choice of post-succession actions. The more predecessors trust their successors, are comfortable dealing with uncertainty and are involved in alternative activities, the more these predecessors adopt a consultative role, providing advice only on issues they are consulted on. While the opposite conditions lead predecessors to adopt roles that provided them oversight over the organization and the successor, allowing them to regularly dictate their wishes to the other stakeholders.

However, the key actor in this dyadic interaction is the successor, to be more specific his or her reaction to the involvement behaviour. Whether a predecessor is involved in a frequent, directive and wide scope way or an infrequent, consultative and limited scope way, they should make sure that their actions are desired by the successors or not. Undesired involvement behaviours, regardless of their type, tend to lead to dysfunctional successor reactions, which tarnishes the dyadic communication and cooperation, eventually preventing predecessors and successors from working together towards the common goal (i.e. the growth and survival of the firm) and hurting the organization that both care about and/or depend on. Hence, it is the responsibility of the predecessors to learn what their successors desire from them post-succession and it is the successors responsibility to properly inform their predecessors what they expect from them. Since mismatch between successor expectations and predecessor behaviours have the potential to disrupt the family harmony and hurt the organization even after the succession is complete, post-succession preparations should be a part of the overall transition plan in family business.

\section{Discussion and Conclusion}

Researchers who view continued predecessor involvement with the family business as a major source of conflict have recommended keeping the predecessors as far away as possible from the family business (Brun de Pontet et al., 2007; Davis \& Harveston, 1998; Harvey \& Evans, 1995; Quigley \& Hambrick, 2012). However, trying to keep predecessors away from the family business would mean the successor and the organization can lose access to valuable resources such as access to personal networks, transfer of idiosyncratic knowledge and experiences learned from the past. In addition, the assumption that predecessors' ties can be easily severed in family business, especially when there is a familial relationship involved, ignores the side channels of informal communication that exist in these organizations (Pieper, 2010). Previous studies (e.g., Aranoff, 1998; Cadieux, 2007; Davis \& Harveston, 1998; Harvey \& Evans, 1995; Pardo-del-Val, 2009; Sonnenfeld, 1988) show that even after predecessors claim they have retired and transferred the baton to their successors, most continue to be involved with the family business and interact with their successors. Predecessors' transfer of title, authority and/or responsibility might signal a change at the executive level, but it does not mean that dyadic interactions, relationships, and effects on the organizational outcomes necessarily end (Harvey \& Evans, 1995). Organizations, especially family businesses, have to be prepared for continued predecessor involvement (Aronoff, 1998). The focus of post-succession preparation should shift from the question "what will the predecessor do after he/she retires?" to "how can we accommodate the predecessor so that they, their successor, the organization and the family can all benefit from this?" Studies show being prepared (via mentality, motivation, knowledge and skill) is significantly related to positive succession outcomes both for the individual and the organization (Chittoor and Das, 2007). 
Predecessors must realize that they add more value to the family and the organization when they build institutions that effectively govern the relationship between family, management, and ownership without the need for continuous micromanagement (Poza, 2007). Predecessors' experience, network connections, and resources are valued and many successors do enjoy working with their parents, but they do not like to be constantly challenged or told what to do (Miller et al., 2003). If predecessors, regardless of their intentions, do not allow the next generation to stand on their own feet, the successors will be highly dependent on the predecessors and will have less desire to take responsibility and eventually hurt the organization (Stravrou, 2003; Cabrera-Suarez, 2005). Predecessors need to recognize that they will not be around indefinitely to oversee their successors; thus, predecessors should provide successors with the space and opportunity to develop their own management style and organizational strategy. On the other hand, successors have to remember to recognize the physical, financial, and psychological investment their predecessors have made to the family business (Cabrera-Suarez et al., 2001).

\subsection{Limitations and Future Research Suggestions}

The research relied primarily on the use of in depth-interviews; thus, the data collected depended on the self-report of participants. The concern with self-reporting is the validity issue, with the accuracy of a self-report depending on many factors including an individual's motivation, perception, and ability to describe (Judd, Smith and Kidder, 1991). To counter the possible negative effects of self-report, several measures were taken. First, participants during the interview were specifically asked to provide both positive and negative examples. The aim was to encourage participants to remember events, interactions and outcomes that could not be denied or idealized. Second and most importantly, the research was designed to collect data from multiple data sources. When possible, both the predecessor and the successor from the same family business were interviewed to compare and contrast interpretations of events and interactions.

Since majority of the participants (and all of the predecessors) were male, the perspectives and concerns mentioned by them might not be reflective of how female predecessors behave after the succession. Female predecessors can be more reluctant to relinquish total control over the business compared to male predecessors (Cadieux et al., 2002). Dumas $(1992,1998)$ has shown that the gender of the successor and the predecessor matters prior to and during the succession process. Comparing and contrasting post-succession behaviours of both genders would be an interesting and valuable extension of this research.

Another future research avenue would be, a growing number of family businesses are now handing over their top positions to successors who have no family connection to their predecessors. In some organizations this is happening in an attempt to professionalize the firm's management, while in others, small family sizes are limiting the chances of finding qualified family member successors (Aldrich \& Cliff, 2003; Bhappu, 2000). Having professionals manage the family business means a separation between ownership and management that can create an interesting dynamic between the predecessor and the successor.

In conclusion, it appears that even after we take the old man out from the business, we cannot take the business out of the old man because the two are integrally intertwined. Hence, when preparing for the succession and afterwards, instead of trying to figure out how to separate predecessors from family businesses, it would be more beneficial to find suitable ways to manage their continued presence. Finally, both predecessors and successor must ensure they properly inform each other about their post-succession expectation.

\section{References}

Aldrich, H. E., \& Cliff, J. E. (2003). The pervasive effects of family on entrepreneurship: toward a family embeddedness perspective. Journal of Business Venturing, 18(5), 573-596. https://doi.org/10.1016/s0883-9026(03)00011-9

Aronoff, C. E. (1998). Megatrends in Family Business. Family Business Review, 11(3), 181-185. https://doi.org/10.1111/j.1741-6248.1998.00181.x

Bass, B. M. (1990). Bass and Stogdill's handbook of leadership: Theory, research and managerial applications. New York, NY: Free Press. https://doi.org/10.1016/1048-9843(93)90006-f

Bhappu, A. D. (2000). The Japanese family: an institutional logic for Japanese corporate networks and Japanese management. Academy of Management Review, 25(2), 409-415. https://doi.org/10.2307/259021

Bjuggren, P., \& Sund, L. (2001). Strategic decision making in intergenerational successions of small and medium size family-owned businesses. Family Business Review, 14(1), 11-24. https://doi.org/10.1111/j.1741-6248.2001.00011.x

Brun de Pontet, S., Wrosch, C., \& Gagne, M. (2007). An exploration of the generational differences in levels of 
control held among family businesses approaching succession. Family Business Review, 20(4), 337-354. https://doi.org/10.1111/j.1741-6248.2007.00103.x

Cabrera-Suarez, K. (2005). Leadership transfer and the successor's development in the family firm. Leadership Quarterly, 16(1), 71-96. https://doi.org/10.1016/j.leaqua.2004.09.010

Cabrera-Suarez, K., De Saa-Perez, P., \& Garcia-Almeida, P. (2001). The succession process from a resource- and knowledge-based view of the family firm. Family Business Review, 14(1), 37-48. https://doi.org/10.1111/j.1741-6248.2001.00037.x

Cadieux, L. (2007). Succession in small and medium-sized family businesses: Toward a typology of predecessor roles during and after instatement of the successor. Family Business Review, 20(2), 95-109. https://doi.org/10.1111/j.1741-6248.2007.00089.x

Cadieux, L., Lorrain, J., \& Hugron, P. (2002). Succession in women-owned family businesses: A case study. Family Business Review, 15(1), 17-30. https://doi.org/10.1111/j.1741-6248.2002.00017.x

Cater, J. J., \& Justis, R. T. (2010). The development and implementation of shared leadership in multi-generational family firms. Management Research Review, 33(6), 563-585. https://doi.org/10.1108/01409171011050190

Chittoor, R., \& Das, R. (2007). Professionalization of management and succession performance - A vital linkage. Family Business Review, 20(1), 65-79. https://doi.org/10.1111/j.1741-6248.2007.00084.x

Chrisman, J. J., Kellermanns, F. W., Chan, K. C., \& Liano, K. (2010). Intellectual foundations of current research in family business: An identification and review of 25 influential articles. Family Business Review, 23(1), 9-26.

Chua, J. H., Chrisman, J. J., \& Sharma, P. (1999). Defining the Family Business by Behavior. Entrepreneurship: Theory and Practice, 23(4), 19-39. https://doi.org/10.1177/104225879902300402

Chung, W., \& Yuen, K. (2003). Management succession: A case study for Chinese family-owned business. Management Decision, 41(7), 643-655. https://doi.org/10.1108/00251740310495577

Danes, S. M., Leichtentritt, R., Metz, M. E., \& Huddleston-Casas, C. (2000). Effects of conflict styles and conflict severity. Journal of Family Economics, 21(3), 259-286. https://doi.org/10.1023/A:1009485301715

Davis, P. S., \& Harveston, P. D. (1998). The influence of family on the family business succession process: A multi-generational perspective. Entrepreneurship: Theory and Practice, 22(3), 31-53. https://doi.org/10.1177/104225879802200302

De Massis, A., Chua, J. H., \& Chrisman, J. J. (2008). Factors preventing intra-family succession. Family Business Review, 21(2), 183-199. https://doi.org/10.1111/j.1741-6248.2008.00118.x

Dumas, C. A. (1992). Integrating the daughter into family business management. Entrepreneurship: Theory and Practice, 16(4), 41-56. https://doi.org/10.1177/104225879201600403

Dumas, C. A. (1998). Women's pathways to participation and leadership in the family owned firm. Family Business Review, 11(3), 219-228. https://doi.org/10.1111/j.1741-6248.1998.00219.x

Dyer, W. G. (1986). Cultural change in family firms: Anticipating and managing business and family transitions. San Francisco, CA: Jossey Bass. https://doi.org/10.2307/2392903

Evans, J. H., Nagarajan, N. J., Schloetzer, J. D. (2010). CEO turnover and retention light: Retaining former CEOs on the board. Journal of Accounting Research, 48(5), 1015-1047. https://doi.org/10.1111/j.1475-679X.2010.00383.x

Feltham, T. S., Feltham, G., \& Barnett, J. J. (2005). The dependence of family business on a single decision maker. Journal of Small Business Management, 43(1), 1-15. https://doi.org/10.1111/j.1540-627X.2004.00122.x

Gilgun, J. F., \& Sussman, M. B. (1996). The methods and methodologies of qualitative family research. Binghamton, NY: Haworth Press. https://doi.org/10.4324/9781315786643

Gioia, D. A., Corley, K. G., \& Hamilton, A. L. (2013). Seeking Qualitative Rigor in Inductive Research Notes on the Gioia Methodology. Organizational Research Methods, 16(1), 15-31. https://doi.org/10.1177/1094428112452151

Glaser, B. G., \& Strauss, A. L. (1967). The discovery of grounded theory. New York, NY: Aldine Publishing Co. The discovery of grounded theory. https://doi.org/10.4324/9780203793206 
Goldberg, S. D. (1996). Effective successors in family-owned business. Family Business Review, 9(2), 185-197.

Gomez-Mejia, L. R., Haynes, K. T., Nunez-Nickel, M., Jacobson, K. J. L., \& Moyano-Fuentes, J. (2007). Socioemotional wealth and business risks in family-controlled firms: Evidence from Spanish olive oil mills. Administrative Science Quarterly, 52(1), 106-137. https://doi.org/10.2189/asqu.52.1.106

Gordon, G., \& Nicholson, N. (2008). Family wars: classic conflicts in the family and how to deal with them. Philadelphia, PA: Kogan Page.

Grassby, R. (2001). Kinship and capitalism. Cambridge: Cambridge University Press.

Grote, J. (2003). Conflicting generations: A new theory of family business rivalry. Family Business Review, 16(2), 113-124. https://doi.org/10.1111/j.1741-6248.2003.00113.x

Handler, W. C. (1989). Managing the family firm succession process: The next-generation family member's experience. Ph.D. thesis, Boston University, UMI Dissertation Services.

Handler, W. C. (1990). Succession in family firms: A mutual role adjustment between entrepreneur and next-generation family members. Entrepreneurship Theory and Practice, 15(1), 37-52. https://doi.org/10.1177/104225879001500105

Harvey, M., \& Evans, R. (1995). Life after succession in the family business: is it really the end of problems? Family Business Review, 12(3), 225-239. https://doi.org/10.1111/j.1741-6248.1995.00003.x

Houkes, I., Janssen, P. P. M., de Jonge, J., \& Bakker, A. B. (2003). Specific determinants of intrinsic work motivation, emotional exhaustion and turnover intention: A multisample longitudinal design. Journal of $\begin{array}{lllll}\text { Occupational and } \quad \text { Organizational } & \text { Psychology, } & 76(4), & \text { 427-450. }\end{array}$ https://doi.org/10.1348/096317903322591578

Jayaraman, N., Khorana, A., Nelling, E., \& Covin, J. (2000). CEO founder status and firm financial performance. Strategic Management Journal, 21(12), 1215-1224. https://doi.org/10.1002/1097-0266(200012)21

Judd, C. M., Smith, E. R., \& Kidder, L. H. (1991). Research methods in social relations (6th ed.). Toronto, ON: Harcourt Brace and Company Canada.

Kets de Vries, M. F. R., Carlock, R. S., \& Florent-Treacy, E. (2007). Family Business on the couch. West Sussex, UK: John Wiley and Sons.

Kim, H., \& DeVaney, S. A. (2003). The expectation of partial retirement among family business owners. Family Business Review, 16(3), 199-211. https://doi.org/10.1177/089448665030160030501

Lansberg, I. (1999). Succeeding generations: Realizing the dream of families in business. Boston, MA: Harvard Business School Press.

Le Breton-Miller, I., \& Miller, D. (2006). Why do some family businesses out-compete? Governance, long-term orientations, and sustainable capability. Entrepreneurship: Theory and Practice, 30(6), 731-746. https://doi.org/10.1111/j.1540-6520.2006.00147.x

Le Breton-Miller, I., Miller, D., \& Steier, L. P. (2004). Toward an integrative model of effective FOB succession. Entrepreneurship: Theory and Practice, 28(4), 305-328. https://doi.org/10.1111/j.1540-6520.2004.00047.x

Ling, Y., Baldridge, D., \& Craig, J. B. (2012). The impact of family structure on issue selling by successor generation members in family firms. Journal of Family Business Strategy, 3(4), 220-227. https://doi.org/10.1016/j.jfbs.2012.10.002

Marshall, C., \& Rossman, G. B. (2006). Designing qualitative research. Thousands Oaks, CA: Sage Publications.

McKee, M. C., \& Driscoll, C. (2008). Creating stabilizers and safety nets for successor executives' high-wire act. Nonprofit Management and Leadership, 18(3), 341-357. https://doi.org/10.1002/nml.189

Miller, D., \&Le Breton-Miller, I. (2005). Managing for the long run: Lessons in competitive advantage from great family businesses. Boston, MA: Harvard Business School Press. https://doi.org/10.1021/la050716d

Miller, D., Steier, L., \& Le Breton-Miller, I. (2003). Lost in time: Intergenerational succession, change, and failure in family business. Journal of Business Venturing, 18(4), 513-531. https://doi.org/10.1016/S0883-9026(03)00058-2

Mitchell, J. R., Hart, T. A., Valcea, S., \& Townsend, D. M. (2009). Becoming the boss: Discretion and post-succession success in family firms. Entrepreneurship: Theory and Practice, 33(6), 1201-1218. 
https://doi.org/10.1111/j.1540-6520.2009.00341.x

Mochon, D., Norton, M. I., \& Ariely, D. (2012). Bolstering and restoring feelings of competence via the IKEA effect. International Journal of Research in Marketing, 29(4), 363-369.

Pardo-del-Val, M. (2009). Succession in family firms from a multistage perspective. International Entrepreneurship and Management Journal, 5(2), 165-179. https://doi.org/10.1007/s11365-008-0092-1

Pelletier, K. L. (2010). Leader toxicity: An empirical investigation of toxic behavior and rhetoric. Leadership, 6(4), 373-389. https://doi.org/10.1177/1742715010379308

Pieper, T. M. (2010). Non solus: Toward a psychology of family business. Journal of Family Business Strategy, 1(1), 26-39. https://doi.org/10.1016/j.jfbs.2010.02.003

Poza, E. J. (2007). Family business (2nd ed.). Manson, OH: Thomson South-Western.

Pratt, M. G. (2009). For the lack of a boilerplate: Tips on writing up (and rewriting) qualitative research. Academy of Management Journal, 52(5), 856-862. https://doi.org/10.5465/amj.2009.44632557

Proost, K., Ruysseveldtb, J., \& Dijkec, M. (2012). Coping with unmet expectations: Learning opportunities as a buffer against emotional exhaustion and turnover intentions. European Journal of Work and Organizational Psychology, 21(1), 7-27. https://doi.org/10.1080/1359432X.2010.526304

Quigley, T. J., \& Hambrick, D. C. (2012). When the former CEO stays on as board chair: Effects on successor discretion, strategic change, and performance. Strategic Management Journal, 33(7), 834-859. https://doi.org/10.1002/smj.1945

Reddy, W. B. (1994). Intervention skills. San Francisco, CA: Jossey-Bass/Pfeiffer. https://doi.org/10.2466/pms.1994.78.1.249

Rosenblatt, P. C., de Mik, L., Anderson, R. M., \& Johnson, P. A. (1985). The family in business, understanding and dealing with the challenges entrepreneurial families face. San Francisco, CA: Jossey-Bass Inc.

Sharma, P., \& Irving, P. G. (2005). Four bases of family business successor commitment: antecedents and $\begin{array}{llll}\text { consequences. } \quad \text { Entrepreneurship: Theory and } & \text { 13-33. }\end{array}$ https://doi.org/10.1111/j.1540-6520.2005.00067.x

Sharma, P., Chrisman, J. J., Pablo, A. L., \& Chua, J. H. (2001). Determinants of initial satisfaction with the succession process in family firms: A conceptual model. Entrepreneurship: Theory and Practice, 25(3), 17-35. https://doi.org/10.1177/104225870102500302

Sharma, P., Chua, J., \& Chrisman, J. (2000). Perceptions about the extent of succession planning in Canadian family firms. Canadian Journal of Administrative Sciences, 17(3), 233-244. https://doi.org/10.1111/j.1936-4490.2000.tb00223.x

Sigalas, C., Chrondrakis, G., Zaharopoulos, A., \& Vozikis, G. (2008). Performance lags and gaps during family business succession: The dual inefficiency of succession discontinuity and lower initial post-succession performance. In J. Butler and P. Phan (Eds.), Theoretical Developments and Future Research in Family Business (pp. 231-260). Charlotte, NC: Information Age Publishing.

Sonnenfeld, J. A. (1988). The hero's farewell: What happens when CEOs retire. New York: Oxford University Press.

Stavrou, E. T. (2003). Leadership succession in owner-managed firms through the lens of extraversion. International Small Business Journal, 21(3), 331-349. https://doi.org/10.1177/02662426030213005

Stavrou, E. T., \& Swiercz, P. M. (1998). Securing the future of the family enterprise: a model of offspring intentions to join. Entrepreneurship: Theory and Practice, 23(2), 19-39.

Steier, L. P., \& Miller, D. (2010). Pre- and post-succession governance philosophies in entrepreneurial family firms. Journal of Family Business Strategy, 1(3), 145-154. https://doi.org/10.1016/j.jfbs.2010.07.001

Stewart, C. C., \& Danes, S. M. (2001). The relationship between inclusion and control in resort family businesses: a developmental approach to conflict. Journal of Family Economics, 22(3), 293-320. https://doi.org/10.1023/A:1016604023763

Strauss, A. L., \& Corbin, J. M. (1990). Basics of qualitative research: Grounded theory procedures and techniques. Newbury Park, CA: Sage.

Turnley, W. H., \& Feldman, D. C. (2000). Re-examining the effects of psychological contract violations: Unmet 
expectations and job dissatisfaction as mediators. Journal of Organizational Behavior, 21(1), 25-42.

Van der Heyden, L., Blondel, C., \& Carlock, R. S. (2005). Fair process: Striving for justice in family business. Family Business Review, 18(1), 1-21. https://doi.org/10.1111/j.1741-6248.2005.00027.x

Venter, E., Boshoff, C., \& Maas, G. (2005). The influence of successor-related factors on the succession process in small and medium-sized family businesses. Family Business Review, 18(4), 283-303. https://doi.org/10.1111/j.1741-6248.2005.00049.x

Wanous, J. P., Poland, T. D., Premack, S. L., \& Davis, K. S. (1992). The effects of met expectations on newcomer attitudes and behaviors: A review and meta-analysis. Journal of Applied Psychology, 77(2), 288-297.

Ward, J. L. (1987). Keeping the family business healthy: How to plan for continuing growth, profitability, and family leadership. San Francisco, CA: Jossey-Bass.

\section{Note}

Note 1. MUSIAD is a non-governmental, non-profit, and voluntary-based organization established in 1990 and has 3150 members.

\section{Copyrights}

Copyright for this article is retained by the author(s), with first publication rights granted to the journal.

This is an open-access article distributed under the terms and conditions of the Creative Commons Attribution license (http://creativecommons.org/licenses/by/4.0/). 